\title{
ASPEK YURIDIS TERHADAP AKUISISI MEREK PERUSAHAAN
} Erlina

\author{
Universitas Islam Negeri (UIN) Alauddin Makassar
}

Email: erlina_fshuin@yahoo.co.id

\begin{abstract}
Building a strong brand needs hard work and a relatively long time. Therefore it will be much faster and less risky when acquiring a brand that is well known and has a loyal market compared to creating a brand or new brand that is not necessarily successful. Acquiring a brand that has been proven to have performance and income and good growth is safer than developing its own brand. But if a misstep, acquisition can actually harm the company, both for the company being acquired and the company that acquires it

Keywords: Acquisitions, Brands, Companies
\end{abstract}

\begin{abstract}
Abstrak
Membangun merek yang kokoh perlu usaha yang keras dan waktu yang relative panjang. Oleh karena itu akan jauh lebih cepat dan kurang berisiko apabila mengakuisisi merek yang sudah dikenal dan memiliki pasar yang loyal dibanding dengan membuat merek atau brand baru yang belum tentu berhasil. Mengakuisisi suatu merek yang sudah terbukti punya kinerja dan pendapatan serta pertumbuhan yang baik lebih aman daripada mengembangkan merek sendiri. Namun kalau salah langkah, akusisi justru bisa merugikan perusahaan, baik bagi perusahan yang diakuisisi maupun perusahaan yang mengakuisisi
\end{abstract}

Kata Kunci: Akuisisi, Merek, Perusahaan 


\section{PENDAHULUAN}

enggabungan perusahaan dapat menumbuhkan kedudukan yang lebih kuat
dalam persaingan dengan perusahaan lain. Penggabungan perusahaan
terjadi apabila dua atau lebih perusahaan bekerja dan diawasi oleh satu interest. Dengan kata lain masih dalam kepemilikan yang sama atau penggendalian dan pengontrolan masih tersentralisasi. Penggabungan perusahaan dapat dilakukan melalui merger dan akuisisi serta konsolidasi.

Akuisisi merupakan trend stategi bisnis dalam tiga decade terakhir, jumlah akuisisi saham perusahan terus berkembang di seluruh dunia. Akuisisi saham atau perusahaan melakukan akuisisi untuk memperluas jaringan usaha. Hal ini didasari oleh keinginan untuk berkembang cepat dalam waktu yang relative singkat. Dengan akuisisi tidak perlu mendirikan perusahaan baru yang belum tentu berhasil tetapi cukup mengambil alih atau membeli saham suatu perusahaan yang sudah ada. Oleh karena itu akuisisi merupakan stategi bisnis yang efesien dan efektif dibanding merger dan konsolidasi. ${ }^{1}$

Akuisisi adalah upaya untuk memperbesar badan usaha dengan cara memiliki badan usaha lain atau memindahkan kepemilikan asal badan usaha lain, sehingga pengendalian terhadap perusahaan tersebut dapat beralih.. Akuisisi perusahaan secara sederhana dapat diartikan sebagai pengambilalihan perusahaan dengan cara membeli saham mayoritas perusahaan sehingga menjadi pemegang saham pengendali. Dalam peristiwa akuisisi, baik perusahaan yang mengambil alih (pengakuisisi) maupun perusahaan yang diambil alih (diakuisisi) tetap hidup sebagai badan hukum yang terpisah. Pengambilalihan perusahaan (akuisisi), sesuai Pasal 1 angka 11 UURI Nomor 40 Tahun 2007 tentang Persoroan Terbatas, adalah perbuatan hukum yang dilakukan oleh badan hukum atau orang perseorangan untuk mengambil alih saham perseroan yang mengakibatkan beralihnya pengendalian atas perseroan tersebut

Akuisisi dapat dilakukan dilakukan dengan membeli seluruh atau sebahagian saham perusahaan ataupun mengakuisisi merek. Akuisisi merek atau perusahaan pemilik merek merupakan suatu strategi atau alternative yang menarik. Dengan akuisisi tersebut sebuah perusahaan dapat melakukan lompatan kuantum dan dapat menjadi perusahaan terbesar.

Akuisisi merek merupakan jalan pintas dalam strategi pertumbuhan an organic. Membangun merek yang kokoh perlu usaha yang keras dan waktu yang relative panjang. Oleh karena itu akan jauh lebih cepat dan kurang berisiko

${ }^{1}$ Joni Emirzon, Akuisisi Lintas Batas Negara dalam Presfektif Hukum Perbankan dan Hukum Persaingan Bisnis, Jurnal Hukum Bisnis, Volume 27 Nomor 2 Tahun 2008, h. 56 
apabila mengakuisisi merek yang sudah dikenal dan memiliki pasar yang loyal dibanding dengan membuat merek atau brand baru yang belum tentu berhasil. Mengakuisisi suatu merek yang sudah terbukti punya kinerja dan pendapatan serta pertumbuhan yang baik lebih aman daripada mengembangkan merek sendiri. Namun kalau salah langkah, akusisi justru bisa merugikan perusahaan, baik bagi perusahan yang diakuisisi maupun perusahaan yang mengakuisisi. ${ }^{2}$ Penguasaaan saham mayoritas oleh pembeli membuat pemilik lama tidak punya andil dalam manajemen baru, tingginya biaya operasional, investasi besar dan lain-lain. Pasca akuisisi, perusahaan dapat memperoleh keuntungan ataupun sebaliknya perusahaan mengalami kerugian. Bagaimana proses berhasilnya sebuah merek yang diakusisi sangat tergantung pada competitive clause. Salah satu contoh, pembeli mensyaratkan penjual merek tidak masuk dalam bisnis yang sejenis untuk waktu tertentu.

\section{PEMBAHASAN}

\section{A. Merek Sebagai Aset Perusahaan}

Dahulu masyarakat bisnis hanya membeli produk atau mengapresiasi produk. Dengan perkembangan zaman, masyarakat bisnis cenderung lebih mengapresiasi merek. Nama, brand atau merek adalah refresentatif suatu produk baik mutu, harga, nilai maupun gengsinya. Merek adalah pembeda produk yang satu dengan yang lain. Merek mempunyai peranan yang sangat penting bagi pemilik suatu produk barang atau jasa. Hal ini disebabkan oleh fungsi merek itu sendiri untuk membedakan dalam memperkenalkan suatu barang dan/atau jasa dengan barang dan/atau jasa lainnya yang mempunyai kriteria dalam kelas barang dan/atau jasa sejenis yang diproduksi oleh perusahaan yang berbeda. Dengan memiliki suatu merek berarti telah dapat diterapkan salah satu strategi pemasaran, yaitu strategi pengembangan produk kepada masyarakat pemakai atau kepada masyarakat konsumen, dimana kedudukan suatu merek dipengaruhi oleh baik atau tidaknya mutu suatu barang yang bersangkutan. Jadi merek akan selalu dicari apabila produk atau jasa yang menggunakan merek mempunyai mutu dan karakter yang baik yang dapat digunakan untuk mempengaruhi pasar.

Merek merupakan tanda. Tanda yang memberi kepribadian atau pengindividualisasian kepada barang-barang. Memberi kepribadian atau

2 Contohnya merek AdeS, sebelum diakuisisi oleh The Coca Company merupakan merek terbesar kedua setelah Aqua, setelah diakuisisi justru kalah dengan merek club dan vit; kecap piring Lombok yang diakuisisi oleh Indofood juga mengalami penurunan omzet; kopi Tugu Luwak yang diakuisisi oleh infood menjadi vakum, tidak ada produksi, distribusi maupun pemasaran. 
pengindividualisasian, dalam arti memberi tanda yang khusus, yang mempunyai daya pembeda (distincti venees) atas barang dengan cara bermacam-macam, antara lain dengan mencetak tanda yang bersangkutan pada barang atau dikaitkan pada barang itu, dengan mengantungkan pelat tanda khusus tersebut. ${ }^{3}$

Merek digunakan sebagai alat untuk membedakan barang dan jasa yang diproduksi oleh suatu perusahaan dari barang dan/atau jasa produksi perusahaan lain yang sejenis, atau digunakan untuk memberikan tanda dari produk yang dihasilkan. Kebijakan dasar suatu merek adalah untuk melindungi iktikad baik dalam penggunaan dengan tanda yang digunakan oleh suatu perusahaan. Hal ini dimaksudkan untuk membedakan identitas barang dan atau jasa. Dengan kata lain hukum merek memiliki tujuan bahwa tanda yang digunakan sebagai merek memiliki daya pembeda (capable of distinguishing) atau daya penentu (individualisering) barang atau jasa yang satu dengan yang lainnya.

Sebuah produk akan dihargai rendah meski fungsi dan manfaatnya sama dengan produk yang mempunyai merek yang kuat. Dengan merek yang kuat harga barang yang sama bisa menjadi berlipat ganda bahkan priceless. Stephen King, CEO WPP Group, London, mendefenisikan produk sebagai barang yang dihasilkan pabrik, sedangkan produk adalah sesuatu yang dicari konsumen. Produk amat mudah ditiru, sementara merek selalu memiliki keunikan dan nilai tambah yang sangat signifikan. Produk cepat usang, sementara merek yang sukses akan bertahan sepanjang zaman.

Menurut Graeme Pitkethly ${ }^{4}$ untuk untuk menemukan suatu inovasi baru yang hebat, tim riset dan pengembangan (R\&D) butuh waktu yang sangat lama. Hal ini akibat pasar semakin tersegmentasi akibatnya promosi tidak efektif. Produk baru jadi sulit untuk berkembang sehingga perusahaan global memilih akuisisi merek local yang bagus demi memperpendek time to market. Sehingga waktu untuk brand building lebih efesien dan efektif. Dari sisi keuangan mengakuisisi merek pada awalnya kelihatan mahal tetapi secara keseluruhan lebih murah dan efektif. Selain itu membeli merek ditempuh untuk mempertahankan probabilitas, hal ini sangat penting bagi perusahaan public untuk mempertahankan probabilitas dihadapan pemegang saham.

Di sisi lain, pemilik merek menjual merek karena tawaran harga yang premium, terlibat maslah mismanajemen, atau kekurangan sumber daya untuk mengembangkan bisnisnya. Namun adapula yang menjual seluruh sahamnnya

3 Harsono Adi Sumarto, 1989, Hak Milik Intelektual Khususnya Merek dan Paten, Akademik Pressindo, Jakarta

${ }^{4}$ Swa Sembada, Edisi Desember 2017, h. 36 
atau penyertaannya karena tidak adanya generasi penerus yang siap melanjutkan pengelolaan merek atau bisnisnya ataupun ingin focus pada merek-merek lain yang menjadi bisnis inti.

Secara umum dalam jual beli merek harus mempertimbangkan aspek substantive perusahaan pemilik merek, termasuk budaya merek, personalitas merek dan flatform. Selain itu factor kesehatan dan kekuatan merek, apa masalahnya, siapa pelanggannya, prospek dan perkiraan nilai mereknya. Selain itu pembeli merek pada umumnya memilih merek yang sudah kuat kinerjanya dan tinggi brand awaress-nya dan masih dikembangkan dengan instrumen promosi tertentu.

\section{B. Akuisisi Merek dan Akuisisi Perusahaan}

Akuisisi berasal dari dari bahasa Inggris "acquisition” yang biasa disebut juga "take over" berarti pengambilalihan suatu kepentingan pengendalian perusahaan oleh perusahaan lain (one company taking over controlling interest another company) $)^{5} \quad$ Undang-undang No. 40 Tentang Perseroan Terbatas menggunakan istilah "pengambilalihan". Akuisisi merupakan tindakan untuk mengambil alih suatu perusahaan oleh perusahaan lain yang biasanya, tetapi tidak selamanya, dicapai dengan membeli saham dari perusahaan lain. Setelah terjadi akuisisi maka kedua perusahaan masih tetap eksis, hanya kepemilikan dan pengendalian atas perseroan yang diambil alih yang berubah. Pasal 1 angka 11 Undang-undang No. 40 Tahun 2007 menentukan bahwa pengambilaalihan adalah perbuatan hukum yang dilakukan oleh badan hukum atau orang perseorangan untuk mengambil alih saham perseroan yang mengakibatkan beralihnya pengendalian atas perseroan tersebut. Berdasarkan defenisi tersebut dapat ditarik beberapa unsur yang melekat didalam pengambilalihan: ${ }^{6}$

1. Pengambilalihan adalah perbuatan hukum

2. Pihak yang mengambilalih adalah badan hukum atau orang

3. Metode pengambilalihan adalah melalui pengambilalihan saham-melalui jual beli

4. Memungkinkan pihak yang mengambilalih perseroan dimaksud menjadi pemegang kendali perseroan yang diambilalih.

5 Munir Fuady, Hukum Tentang Akuisisi, Take Over, dan LBO, Citra Aditya Bakti, Bandung, 2008, h. 3

${ }^{6}$ Ridwan Khairandy, Perseroan Terbatas, Doktrin, Peraturan Perundang-Undangan, dan Yurisprudensi, Kreasi Total Media, Yogyakarta, 2007, h. 310-311 
Bentuk dasar pengambilalihan, berdasarkan jenis usaha dibedakan atas : ${ }^{7}$

1. Akuisisi Horisontal

Akuisisi ini dilakukan terhadap perusahaan lain yang mempunyai bisnis atau bidang usaha yang sama. Perusahaan yang diakuisisi dan yang mengakuisisi bersaing untuk memasarkan produk yang mereka tawarkan.

2. Akuisisi vertikal

Akuisisi ini dilakukan terhadap perusahaan yang berada pada tahap proses produksi yang berbeda.

3. Akuisisi konglomerat

Perusahaan yang mengakuisisi dan yang diakuisisi tidak mempunyai keterkaitan operasi.

Bentuk dasar pengambilalihan, berdasarkan objek transaksi dibedakan atas: ${ }^{8}$

1. Akuisisi saham, untuk dapat disebut transaksi akuisisi, maka saham yang dibeli harus paling sedikit $51 \%$ atau paling tidak setelah proses akuisisi, pihak pengakuisisi memegang saham $51 \%$ sehingga perusahaan target bisa dikontrol. Kalau kurang $51 \%$ berarti hanya jual beli saham biasa dan bukan akuisisi

2. Akuisisi Aset, suatu perusahaan dapat mengakuisisi perusahaan lain dengan jalan membeli aktiva perusahaan target tanpa ikut mengambil alih seluruh kewajiban perusahaan target terhadap pihak ketiga.

3. Akuisisi kombinasi, adalah kombinasi akuisisi saham dengan akuisisi asset.

4. Akuisisi bertahap, akuisisi tidak dilakukan secara sekaligus tetapi perusahaan target menerbitkan convertible bonds, sementara perusahaan pengakuisisi menjadi pembelinya. Tahap pertama perusahaan pengakuisisi mendrop dana ke perusahaan target lewat pembelian bonds. Tahap selanjutnya bond tersebut ditukar dengan equity, jika kinerja perusahaan target semakin baik, hak opsi ada pada pemegang convertible bonds yaitu perusahaan pengakuisisi .

Bentuk dasar pengambilalihan berdasarkan motivasi dibedakan atas: ${ }^{9}$

1. Akuisisi strategis, adalah untuk meningkatkan produktivitas perusahaan sehingga dapat meningkatkan sinergi usaha, mengurangi risiko (karena

${ }^{7}$ Munir Fuady, Hukum Perusahaan Dalam Paradigma Hukum Bisnis, Pt. Citra Aditya, Bandung, 2002, h. 206

${ }^{8}$ Ibid, h.209

${ }^{9}$ Opcit, Swa Sembada h.48 
diversifikasi), memperluas pangsa pasar, meningkatkan efesiensi dan sebagainya

2. Akuisisi finansial, akuisisi dilakukan semata-mata untuk memperoleh keuntungan saja dalam waktu yang singkat. Akuisisi ini bersifat spekulatif, dengan keuntungan yang diharapkan lewat pembelian saham/asset yang murah tetapi dengan income perusahaan target yang tinggi.

Bentuk dasar pengambilalihan berdasarkan divestiture yaitu dengan melihat perlihanaset/saham/manajemen dari perusahaan target kepada perusahaan pengakuisisi terdiri atas: take over, freezeouts, squeezeeouts, management buyouts, leveraged buyouts, inbreng saham atau share swap.

Latar belakang yuridis akuisisi dilakukan dengan maksud sebagai berikut: ${ }^{10}$

1. memperbesar pangsa pasar (market share);

2. memperoleh manfaat perpajakan atau keuangan atau pendapatan bahwa pihaknya sanggup mempertyinggi atau memperbesar penghasilan atau keuntungan pada perusahaan yang diambil alih

3. memperbesar pemasokan atau bahan-bahan baku

4. menyuntik dana kepada perusahaan target yang mengalami kesulitanlikuiditas melalui penerapan akuisisi dengan dalih diversifikasi, sebagai wujud dari taktik "transfer profit" diantara perusahaan satu atap atau kepemilikan yang sama

5. untuk ekspansi usaha atau memperluas usahanya dalam bidang kegiatan yang telah atau akan ditutup

6. mengusahakan agar biaya atau pengeluaran atas penelitian dan pengembangan dapat lebih efesien, efektif, dan produktif

7. sebagai cara untuk menjalankan hubungan bisnis dan menjalankan kerjasama

8. menyehatkan kembali perusahaan yang sedang dalam kesulitan karena kelebihan kapasitas produksi yang tidak dimanfaatkan

9. meningkatkan daya saing perusahaan

10. memperbaiki system manajemen.

Berdasarkan hal tersebut dapat disimpulkan bahwa dengan melakukan akuisisi akan berdampak pertumbuhan perusahaan serta dapat menciptakan

${ }^{10}$ Joni Emirzon, Hukum Bisnis Indonesia, Literata Lintas Media, Jakarta, 2007, h. 118119 
perkembangan dunia usaha yang dinamis, sehat dan berkepastian hukum. Manfaat Akuisisi: ${ }^{11}$

1. Kelangsungan perusahaan terjamin;

2. Pengaruh persaingan dapat diatasi;

3. Kedudukan atau keuangan PT bertambah kuat;

4. Arus barang ke pasar terjamin;

5. Perusahaan yg merugi menjadi stabil;

6. Mutu barang dapat ditingkatkan;

7. Pajak bisa dikurangi dgn memecah perusahaan menjadi unit yg lebih kecil Sedangkan kekurangan akuisisi adalah:

8. Pemegang saham minoritas makin lama makin terdesak oleh pemegang saham mayoritas \& akhirnya seluruh saham perseroan akan dikuasai oleh perseroan pengakuisisi

9. Secara diam-diam akuisisi cenderung menuju kepada pemusatan kekuatan ekonomi pada kelompok perseroan tertentu dalam bentuk monopoli

10. Pemasukan pendapatan negara disektor pajak disektor pajak akan berkurang

\section{Analisis Hukum Akuisisi Merek dan Akuisisi Perusahaan}

Pada umumnya transaksi merek membutuhkan persiapan dan proses yang panjang. Proses akuisisi merek mempunyai sifat yang berbeda satu sama lainnya,. Tidak ada dua proses akuisisi yang sama. Namun dalam proses akuisisi merek harus diseimbangkan antara kecepatan market entry dan kekuatan merek dibandingkan dengan biaya dan risiko akuisisi. ${ }^{12}$ Bentuk akuisisi merek beragam, pertama; membeli merek sekaligus memproduksinya, kedua; kerjasama asistensi teknis, ketiga; hanya membeli mereknya saja.

Banyak faktor yang harus dipertimbangkan dalam melakukan akuisisi merek. Sebelum akuisisi berlangsung kedua pihak harus membahas secara mendetail syarat dan kondisi awal, maksud dan tujuan jelas dan dimengerti kedua pihak. Setelah itu barulah dilakukan proses due diligence, dimulai dengan riset mendalam mengenai positioning merek di pasar beserta karakteristiknya. Hal tersebut harus didukung oleh tinjauan keuangan yang terperinci, pengecekan badan hukum, apakah merek dagang tersebut sah dan tidak dalam keadaan sengketa.

${ }^{11}$ Ahmad M. Ramli, “ Tanggung Jawab PT sebagai Badan Hukum”, Seminar Corporate Law Executive Program, 29-30 Agustus 1995, Jakarta, hal 21

${ }^{12}$ Swa Sembada, op cit, h. 38 
Due diligence atau legal audit sangat penting dipertimbangkan untuk memutuskan dilakukan atau tidaknya deal akuisisi. Legal auidit tersebut dituangkan dalam suatu laporan pemeriksaan hukum (legal audit report). ${ }^{13}$ Laporan tersebut menyangkut masalah hukum muali dari yang kecil bahkan tidak nampak namun berpotensi mengancam eksistensi perusahaan. Hal tersebut antara lain berdampak pada ancaman kepailitan perusahaan, pencabutan izin usaha oleh pemerintah, penyitaan aset utama perusahaan oleh pengadilan atau aparat hukum yang berwenang ataupun pihak krediturnya.

Namun yang paling utama adalah adanya kejelasan tujuan dari semua pihak yang terlibat dan dipertahankannya integritas yang tinggi. John H. Dunning menunjukkan 6 (enema) kriteria yang harus ada agar suatu akuisisi bisa berhasil: ${ }^{14}$

1. Mengurangi ongkos-ongkos transaksi

2. Menghindari berkurangnya gain karena kehilangan kontral

3. Tetap melakukan control terhadap supply inputs

4. Menghadapi intervensi pemerintah secara baik

5. Melindungi hak dan kepemilikan

6. Optimalkan kapasitas yang ada, ambil manfaat dari ukuran besarnya perusahaan, dari produksi bersama atau dari integrasi/diversifikasi.

Sedang penentuan harga perusahaan yang akan diakuisisi factor-faktor pokok yang harus dipertimbangkan adalah sebagai berikut: ${ }^{15}$

1. Harga dari aset-aset perusahaan target, baik yang terdapat dalam balance sheet ataupun yang berada di luar balance sheet

2. Harga dari factor non aset, semisal harga kedudukan perusahaan target dengan para kompetitornya, besarnya risiko, investasi, kekuatan dan ketersediaan sumber daya manusia dan keuntungan-keuntungan yang lain

3. Harga dari pengkonversian perusahaan target menjadi perusahaan yang berproduksi dengan kapasitas dan penghasilan maksimun. Perhitungkan juga harga dari liabilities yang tersembunyi atau yang kontinjen dari perusahaan target.

Disamping persiapan-persiapan dari suatu akuisisi, maka perlu diperhatikan beberapa factor utama yang mempengaruhi keberhasilan suatu akuisisi. Proses akuisisi akan berhasil apabila memperhatikan tahap-tahap proses

\footnotetext{
${ }^{13}$ Munir Fuady, Hukum Tentang Akuisisi, Take Over dan LBO, h.111

${ }^{14}$ Ibid, h. 43-44

${ }^{15}$ Ibid, h.44
} 
akuisisi mulai dari tahap pra akuisisi atau persiapan, saat setelah selesai akuisisi, dalam 5 (lima) tahun pertama setelah akuisisi. Pada intinya proses akuisisi akan berhasil dengan baik, bukan hanya ditentukan pada saat negosiasi, integrasi tetapi juga pada saat pasca akuisisi. Selain informasi pokok diperlukan checklist investigasi bisnis ${ }^{16}$ dan checklist investigasi legal ${ }^{17}$ untuk akuisisi perusahaan yang disesuaikan dengan kebutuhan dari sifat dari perusahaan tersebut.

Selain factor utama yang mempengaruhi berhasilnya suatu akuisisi ataupun akuisisi merek adalah lingkungan bisnis. Produk-produk global Heinz yang sukses diberbagai Negara belum tentu relevan dan efektif untuk dipasarkan di Indonesia. Oleh karena itu, manajemen bisnis HJ Heinz Co. Ltd. ${ }^{18}$ memilih untuk mengakuisisi saham PT. ABC Food Industry ${ }^{19}$. Heinz tidak menggunakan merek globalnya untuk masuk ke pasar Indonesia merek ABC sudah sangat kuat mengakar di Indonesia dan justru mengganti merek tidak relevan bagi konsumen. Alasannya produk makanan sangat tergantung pada selera dan selera daerah sangat spesifik. Perusahan ini lebih focus pada pertumbuhan pasca akuisisi yaitu posisi pangsa pasar, target, dan perkembangannya. Perusahaan focus pada promosi, pemasaran dan eksekusi ke jaringan ritel. Selain itu adalah profesionalisasi organisasi terutama karyawan. Misalnya dalam hal mengakses teknologi dan data baik dibidang riset, pemasaran, dan pengembangan.

Dalam praktik, akuisisi merek yang merupakan salah satu bentuk akuisisi saham mengalami perkembangan yang cukup pesat. Hal ini diakibatkan dari sifat merek itu sendiri yang mampu mempercepat penetrasi pasar. Perkembangan akuisisi merek perlu disikapi secara seksama oleh semua pihak, apakah akuisisi tersebut sesuai tujuannya, apakah akuisisi tersebut telah sesuai dengan regulasi hukum bisnis di Indonesia (Undang-undang Perseroan Terbatas, Undang-undang Anti Monopoli dan lain-lain).

Dalam undang-undang No. 40 Tahun 2007 Tentang Perseroan terbatas, mengatur tentang kegiatan akuisisi sebagaimana diatur dalam pasal 126 UUPT

16 Meliputi corporate background, basis of proposed, acquisition, finansial, product, sales, management and industrial relations, facilities, engeneering, technical service, and research, control, outlook for buyer

${ }^{17}$ Meliputi state law; seller's corporate organization, power and commitment (seller and all subsidiaries); assets (seller and all subsidiaries); contracts; liabilities; antitrust considerations; taxesbrokerage; securities and exchange commission; stock exchange requirements

${ }^{18}$ Portofolio bisnis yang dimiliki oleh HJ Heinz Co. Ltd. fokus pada consumer goods

${ }^{19}$ HJ Heinz Co. Ltd. Mengakuisisi $75 \%$ saham PT ABC Central Food Industry, berubah nama menjadi PT Heinz ABC Indonesia. 
yang menentukan bahwa: Perbuatan hukum Penggabungan, Peleburan, Pengambilalihan, atau Pemisahan wajib memperhatikan kepentingan:

a. Perseroan, pemegang saham minoritas, karyawan Perseroan;

b. kreditor dan mitra usaha lainnya dari Perseroan; dan

c. masyarakat dan persaingan sehat dalam melakukan usaha.

Berdasarkan ketentuan pasal 126 UUPT memberikan legitimasi akuisisi terhadap merek ataupun perusahaan pemilik merek, namun tetap memperhatikan proses akuisisi. Baik pada tahap persiapan, tahap negosiasi maupun tahap integrasi. Di sisi lain untuk melakukan pengambilalihan saham perusahaan lain apabila tindakan tersebut dapat mengakibatkan terjadinya praktek monopoli dan persaingan usaha yang tidak sehat. Dengan demikian akuisisi tidak dapat dilakukan kalau akan merugikan pihak-pihak tertentu. Selanjutnya dalam melakukan akuisisi harus dicegah kemungkinan terjadinya monopoli. ${ }^{20}$ Dalam melakukan akuisisi harus memperhatikan ketentuan pasal 28 dan pasal 29 undangundang No. 5 Tahun 1999. Pembuktian pasal ini menggunakan pendekatan rule of reason. Rule of reason bearti penerapan aturan sangat tergantung pada akibat yang ditimbulkan oleh perbuatan yang dilakukan pelaku usaha, yaitu apakah akibat yang dilarang oleh UU melahirkan praktek monopoli dan atau persaingan usaha tidak sehat benar-banar terjadi.

Adapun dokumentasi yang diperlukan untuk akusisi perusahaan:

1. PERSIAPAN AKUISISI

a. Memorandum of Understanding (MOU).

b. Checklist Bisnis.

c. Checklist Hukum.

2. PELAKSANAAN AKUISISI
a. Kontrak Akuisisi.
b. Laporan Due Diligince Hukum (Legal Audit).
c. Laporan Keuangan dari Akuntan.
d. Laporan Penilai dari Appraiser.
e. Rancangan Akusisi.
f. Man Akusisi.
g. Dokumen yang Berkenaan dengan Pinjaman dan Financing Jika Akusisi Berupa LBO/MBO.

\section{SETELAH AKUISISI}

a. Kontrak-kontrak.

${ }^{20}$ Abdulkadir Muhammad, Hukum Perusahaan Indonesia, PT Citra Aditya Bhakti, Bandung, 2006, h. 339 
b. Dokumen dengan karyawan.

c. Dokumen hutang.

d. Dokumen internal perusahaan.

e. Dokumen Aset perusahaan.

f. Dokumen dengan Supplier.

g. Dokumen dengan pihak perantara.

h. Dokumen dengan pihak profesional.

i. Dokumen dengan pihak terafiliasi.

j. Dokumen dengan pihak ketiga lainnya.

4. DOKUMENTASI KHUSUS UNTUK PERSEROAN TERBUKA

a. Rencana dan Rancangan Akusisi.

b. Circulair Letter kepada Pemegang Saham.

c. Dokumen Tender, jika perusahaan target adalah Perusahaan Terbuka.

d. Pengunguman-pengunguman di koran.

e. Pendapat-pendapat para profesional (akuntan, lawyer, appraiser).

\section{PENUTUP}

Ada beberapa faktor utama yang mempengaruhi keberhasilan suatu akuisisi. Proses akuisisi akan berhasil apabila memperhatikan tahap-tahap proses akuisisi proses mulai pada saat negosiasi, integrasi, dan pasca akuisisi. Selain informasi pokok diperlukan checklist investigasi bisnis dan checklist investigasi legal 


\section{DAFTAR PUSTAKA}

Abdulkadir Muhammad, Hukum Perusahaan Indonesia, PT Citra Aditya Bhakti, Bandung, 2006,

Ahmad M. Ramli, “ Tanggung Jawab PT sebagai Badan Hukum”, Seminar Corporate Law Executive Program, 29-30 Agustus 1995, Jakarta

Joni Emirzon, Hukum Bisnis Indonesia, Literata Lintas Media, Jakarta, 2007,

Akuisisi Lintas Batas Negara dalam Presfektif Hukum Perbankan dan Hukum Persaingan Bisnis, Jurnal Hukum Bisnis, Volume 27 Nomor 2 Tahun 2008,

Harsono Adi Sumarto, 1989, Hak Milik Intelektual Khususnya Merek dan Paten, Akademik Pressindo, Jakarta

Munir Fuady, Hukum Perusahaan Dalam Paradigma Hukum Bisnis, Pt. Citra Aditya, Bandung, 2002,

, Hukum Tentang Akuisisi, Take Over, dan LBO, Citra Aditya Bakti, Bandung, 2008,

Ridwan Khairandy, Perseroan Terbatas, Doktrin, Peraturan PerundangUndangan, dan Yurisprudensi, Kreasi Total Media, Yogyakarta, 2007, 